\title{
PRODUCTION OF AMYLASES BY ASPERGILLUS TAMARII
}

\author{
Fabiana Guillen Moreira; Francieli Arrias de Lima; Sophia Renata Fazzano Pedrinho; \\ Veridiana Lenartovicz; Cristina Giatti Marques de Souza; Rosane Marina Peralta*
}

\author{
Departamento de Bioquímica, Universidade Estadual de Maringá, Maringá, PR, Brazil.
}

Submitted: February 09, 1999; Approved: May 11, 1999

\begin{abstract}
A strain of Aspergillus tamarii, a filamentous fungus isolated from soil, was able to produce both $\alpha$-amylase and glucoamylase activities in mineral media supplemented with $1 \%(\mathrm{w} / \mathrm{v})$ starch or maltose as the carbon source. Static cultivation led to significantly higher yields than those obtained using shaking culture. The production of amylases was tolerant to a wide range of initial culture $\mathrm{pH}$ values (from 4 to 10) and temperature (from 25 to $42^{\circ} \mathrm{C}$ ). Two amylases, one $\alpha$-amylase and one glucoamylase, were separated by ion exchange chromatography. Both partially purified enzymes had optimal activities at $\mathrm{pH}$ values between 4.5 and 6.0 and were stable under acid conditions (pH 4.0-7.0). The enzymes exhibited optimal activities at temperatures between $50^{\circ}$ and $60^{\circ} \mathrm{C}$ and were stable for more than ten hours at $55^{\circ} \mathrm{C}$.
\end{abstract}

Key words: $\alpha$-amylase, Aspergillus tamarii, glucoamylase.

\section{INTRODUCTION}

A variety of industries (e.g. food, chemical, detergent, textile) employ microbial amylolytic enzymes to convert starch into different sugar solutions $(2,13,15,18)$. Several types of enzymes are involved in the degradation of starch, mainly $\alpha$ amylase $(1,4 \alpha$-glucan glucanohydrolase, EC 3.2.1.1), $\beta$-amylase $(1,4 \alpha$-glucan maltohydrolase, EC 3.2.1.2), and glucoamylase (1,4 $\alpha$-glucan glucohydrolase, EC 3.2.1.3) $(2,8)$. These enzymes are common in fungi, and Aspergillus sp and Rhizopus sp are often used as sources of industrial amylases (3). Although genetic manipulation by classical mutation techniques and recombinant DNA technology are frequently used to increase the expression levels of a large number of microbial enzymes, including amylases, in well-known microorganisms, traditional screening procedures make possible to find new attractive wild microorganisms able to produce useful enzymes. Some environments such as fertile soil, have great variety of microbial populations. Hundred of different species of fungi inhabit the soil, especially near the soil surface where aerobic conditions prevail (2). Such fungi are active in degrading a wide variety of biological materials present in the soil. They thrive on such material by secreting extracellular enzymes able to degrading large polymeric plant molecules such as cellulose, hemicellulose, starch and pectin, with subsequent assimilation of the liberated nutrients. Considering that a strain of Aspergillus tamarii isolated by soil during a screening programme for xylanase producing microorganisms

\footnotetext{
* Corresponding author. Mailing address: Departamento de Bioquímica, Universidade Estadual de Maringá, CEP 87020-900, Maringá, PR, Brasil. E-mail: rmperalta@pbc.uem.br
} 
(7) showed great growth rate in starch as the only carbon source, the purpose of this work was to investigate the ability of Aspergillus tamarii to produce amylases as well as the effect of $\mathrm{pH}$ and temperature in the enzyme activity.

\section{MATERIALS AND METHODS}

Microorganism and culture conditions: Aspergillus tamarii was isolated from soil during a screening programme for xylanase-producing microorganisms (7). It was deposited in the Fundação Tropical de Pesquisas e Tecnologia André Tosello Collection, Campinas, Brazil. In the lab, it was routinely maintained on potato dextrose agar at $4^{\circ} \mathrm{C}$. The cultures were developed on $250 \mathrm{ml}$ Erlenmeyer flasks containing $50 \mathrm{ml}$ of Vogel salts (10), and various carbon sources $(1 \%, \mathrm{w} / \mathrm{v})$ at $30^{\circ} \mathrm{C}$ on a rotary shaker at $120 \mathrm{rpm}$ or under static condition. Flasks were harvested at periodic intervals, the contents filtered through tared filter paper and the mycelia dried to constant weigh at $60^{\circ} \mathrm{C}$. The filtrates were assayed for $\alpha$-amylase and glucoamylase activities, and protein. Results were expressed as the mean of at least three independent measurements. Residual maltose and starch concentrations in the culture filtrates were estimated using anthrone reagent (6).

Enzyme assays: Two different methods were used to quantify the glucoamylase and $\alpha$-amylase activities in the culture filtrates. Firstly, total amylase activity was estimated by analysis of reducing sugars released during hydrolysis of $0.5 \%(\mathrm{w} / \mathrm{v})$ starch in $0.05 \mathrm{M}$ phosphate buffer $\mathrm{pH} 6.0$ at $40^{\circ} \mathrm{C}$ by the dinitrosalicylic acid method (9). Secondly, glucoamylase activity (EC 3.2.1.3) was estimated by determining the D-glucose content released during hydrolysis of starch by the peroxidase-glucose oxidase assay (1). Finally, $\alpha$-amylase activity (EC 3.2.1.1) was estimated by deducting the reducing sugars from the values of D-glucose determined enzymatically. One unit of amylase activity was defined as the amount of enzyme that releases $1 \mu \mathrm{mol}$ of reducing sugar as D-glucose per min under the assay conditions. The results are presented as specific activity (U/mg extracellular protein). Extracellular proteins were estimated as described by Bradford (4) using bovine serum albumin as the standard.

Separation of the $\alpha$-amylase and glucoamylase activities of the culture filtrates: The culture filtrates were concentrated by precipitation with 3 volumes of acetone at $4^{\circ} \mathrm{C}$, the pellet dissolved in $0.01 \mathrm{M}$ phosphate buffer, $\mathrm{pH} 6.8$, and charged on to a DEAE-cellulose column $(1.5 \times 20 \mathrm{~cm})$ equilibrated with the same buffer. The column was washed with 10 bed volumes of buffer and the protein adsorbed in the column was eluted with a linear gradient of $\mathrm{NaCl}(0-0.50 \mathrm{M})$ in the same buffer at $15 \mathrm{ml} / \mathrm{h}$. Each fraction $(2.5 \mathrm{ml})$ obtained during washing and elution was assayed for amylase activity and absorbance at $280 \mathrm{~nm}$.

Chromatography of hydrolysis products: The pattern of soluble starch hydrolysis by amylolytic enzymes from $A$. tamarii was examined using paper chromatography. Amylases I and II from A. tamarii were incubated with $1.0 \mathrm{ml}$ of solution containing $1 \%$ of starch in $0.05 \mathrm{M}$ phosphate buffer, $\mathrm{pH}$ 6.0. After 30 and $60 \mathrm{~min}$, the reactions were stopped by boiling and stored at $4^{\circ} \mathrm{C}$. Samples $(15 \mu \mathrm{l})$ were spotted onto Whatman $\mathrm{N}^{\circ} 1$ chromatographic paper and descending chromatography carried out at room temperature with a benzene:n-butanol:piridine:water (1:5:3:3) solvent system. The chromatograms were stained with silver nitrate (17).

Chemicals: Starch, amylopectin, amylose, glycogen, maltose, and glucose were obtained from Sigma Chemical Corp. (St. Louis, Mo). All other reagents were of analytical grade.

\section{RESULTS AND DISCUSSION}

The ability of $A$. tamarii to grow and to produce amylases on different carbon sources was studied. Significant growth of $A$. tamarii was observed on monosaccharides, disaccharides and polysaccharides 6 days-cultures (Table 1). The existence of low level constitutive production of glucoamylase and $\alpha$ amylase was detected in sucrose, cellobiose, glucose and raffinose cultures, but active synthesis of both enzymes took place only during growth on maltose, starch, amylose, amylopectin and glycogen. Although higher biomass levels were obtained with shaking cultures, a four-fold increase in both glucoamylase and $\alpha$-amylase activities was observed under static conditions. For this reason, static conditions were used in all following experiments.

A typical time course of extracellular $\alpha$-amylase and glucoamylase production is shown in Fig. 1A-1B. Maximal activities were attained on day 4 and 6 , 
Table 1. Effect of the carbon source on growth and amylase production by Aspergillus tamarii.

\begin{tabular}{|c|c|c|c|c|}
\hline \multirow[b]{2}{*}{$\begin{array}{l}\text { Carbon source } \\
(1 \%, w / v)\end{array}$} & \multicolumn{2}{|c|}{ Static conditions } & \multicolumn{2}{|c|}{ Shaking conditions } \\
\hline & $\begin{array}{l}\text { biomass } \\
\text { (mg) }\end{array}$ & $\begin{array}{c}\text { total amylase } \\
(\mathrm{U} / \mathrm{mg})\end{array}$ & $\begin{array}{l}\text { biomass } \\
\text { (mg) }\end{array}$ & $\begin{array}{l}\text { total amylase } \\
(\mathrm{U} / \mathrm{mg})\end{array}$ \\
\hline none & $28 \pm 5$ & $15 \pm 2$ & $45 \pm 5$ & $8 \pm 1$ \\
\hline sucrose & $260 \pm 30$ & $24 \pm 3$ & $317 \pm 40$ & $10 \pm 2$ \\
\hline cellobiose & $250 \pm 21$ & $25 \pm 3$ & $320 \pm 28$ & $12 \pm 2$ \\
\hline glucose & $355 \pm 30$ & $10 \pm 2$ & $440 \pm 50$ & $7 \pm 1$ \\
\hline raffinose & $215 \pm 23$ & $68 \pm 8$ & $320 \pm 40$ & $20 \pm 2$ \\
\hline maltose & $284 \pm 30$ & $155 \pm 16$ & $410 \pm 37$ & $38 \pm 5$ \\
\hline glycogen & $310 \pm 27$ & $180 \pm 21$ & $480 \pm 51$ & $47 \pm 6$ \\
\hline starch & $290 \pm 32$ & $176 \pm 15$ & $440 \pm 48$ & $42 \pm 4$ \\
\hline amylopectin & $289 \pm 35$ & $170 \pm 20$ & $490 \pm 53$ & $40 \pm 5$ \\
\hline amylose & $380 \pm 42$ & $144 \pm 16$ & $400 \pm 37$ & $32 \pm 2$ \\
\hline
\end{tabular}

The cultures were grown in $250 \mathrm{ml}$ Erlenmeyer flasks containing $50 \mathrm{ml}$ minimal medium supplemented with various carbon sources at $1 \%(\mathrm{w} / \mathrm{v})$ under static or shaking conditions for 6 days at $30^{\circ} \mathrm{C}$. The mycelia (biomass) were separated by filtration and dried to constant weigh at $60^{\circ} \mathrm{C}$. One unit of total amylase (glucoamylase plus $\alpha$-amylase) was defined as the amount of enzymes that releases $1 \mu$ mol of reducing sugar as D-glucose per min. under the assay conditions. The results are presented as specific activity (U/mg extracellular protein). The results express the media $\pm \mathrm{SD}$ of three different experiments.
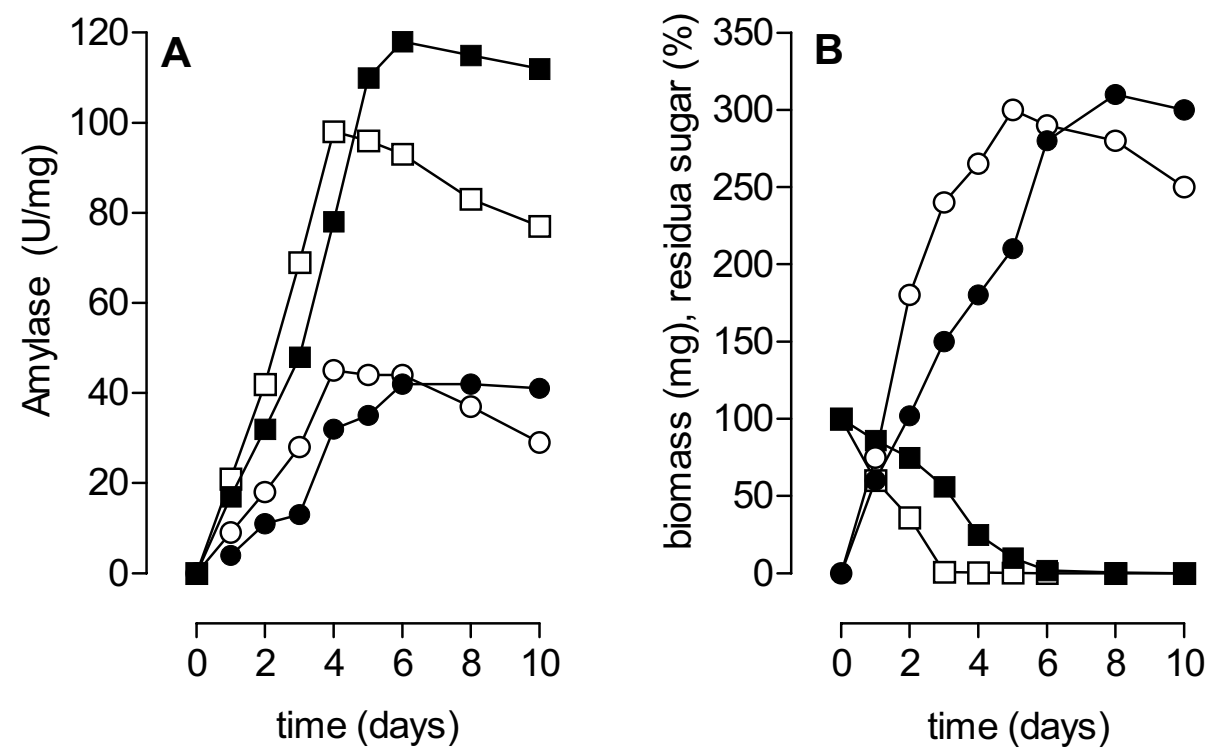

Figure. 1. Time course of amylase and biomass production by Aspergillus tamarii.

A: (ロ) $\alpha$-amylase activity on starch culture; $(\square) \alpha$-amylase activity on maltose culture: $(\bigcirc)$ glucoamylase activity on starch culture; (O) glucoamylase activity on maltose culture; B: (O) biomass production on starch culture; $(\mathrm{O})$ biomass production on maltose culture; (匹) residual starch; $(\square)$ residual maltose.

respectively for the maltose and starch cultures, at the same time of the peak of maximal biomass production. A decrease in enzyme production was observed once the stationary phase of the culture had began. Similar results were obtained in several other microorganisms $(12,14,16)$. Less than $5 \%$ of the initial concentration of maltose or starch was present in the filtrate cultures after 4 days of incubation (Fig. 1B). No significant amounts of glucose were detected in the culture filtrates, suggesting that this sugar was rapidly consumed by the fungus (data not shown). 
Studies on the effect of the initial $\mathrm{pH}$ and temperature on the enzyme production and growth were carried out within the $\mathrm{pH} 3$ to 12 and temperature range 28 to $45^{\circ} \mathrm{C}$. At $30^{\circ} \mathrm{C}$, growth and enzyme production were inhibited when the initial $\mathrm{pH}$ of the medium was above 10 or below 4 (Table 2). The optimal temperature for growth and enzyme production was $30^{\circ} \mathrm{C}$ (Table 3 ). Temperatures between $30^{\circ}$ and $42^{\circ} \mathrm{C}$ had little influence on growth and amylase production. However, the fungus did not grow at temperatures above $42^{\circ} \mathrm{C}$.

Table 2. Effect of initial $\mathrm{pH}$ on amylase production by $A$. tamarii

\begin{tabular}{ccccc}
\hline $\begin{array}{c}\text { Initial } \\
\mathrm{pH}\end{array}$ & $\begin{array}{c}\text { final } \\
\mathrm{pH}\end{array}$ & $\begin{array}{c}\text { biomass } \\
(\mathrm{mg})\end{array}$ & $\begin{array}{c}\text { glucoamylase } \\
(\mathrm{U} / \mathrm{mg})\end{array}$ & $\begin{array}{c}\alpha \text {-amylase } \\
(\mathrm{U} / \mathrm{mg})\end{array}$ \\
\hline 3 & 4.35 & $\mathrm{ND}$ & $\mathrm{ND}$ & $\mathrm{ND}$ \\
4 & 5.38 & $248 \pm 20$ & $128 \pm$ & $30 \pm 3$ \\
5 & 6.28 & $279 \pm 32$ & $129 \pm$ & $31 \pm 4$ \\
6 & 6.90 & $295 \pm 28$ & $136 \pm$ & $35 \pm 3$ \\
7 & 7.10 & $256 \pm 29$ & $130 \pm$ & $32 \pm 5$ \\
8 & 7.18 & $254 \pm 21$ & $131 \pm$ & $32 \pm 3$ \\
9 & 7.47 & $213 \pm 26$ & $125 \pm$ & $29 \pm 3$ \\
10 & 7.68 & $208 \pm 29$ & $121 \pm$ & $28 \pm 4$ \\
11 & 9.20 & $\mathrm{ND}$ & $\mathrm{ND}$ & $\mathrm{ND}$ \\
\hline
\end{tabular}

The cultures were grown in $250 \mathrm{ml}$ Erlenmeyer flasks containing $50 \mathrm{ml}$ minimal medium supplemented with $1 \%(\mathrm{w} / \mathrm{v})$ starch under static conditions for 6 days at $30^{\circ} \mathrm{C}$ at different initial $\mathrm{pH}$. After autoclaving the medium, $\mathrm{pH}$ was adjusted using sterilized $10 \%$ $(\mathrm{w} / \mathrm{v}) \mathrm{Na}_{2} \mathrm{CO}_{3}$ solution or $5 \mathrm{~N} \mathrm{HCl}$. The mycelia (biomass) were separated by filtration and dried to constant weigh at $60^{\circ} \mathrm{C}$. One unit of amylase (glucoamylase and $\alpha$-amylase) was defined as the amount of enzymes that releases $1 \mu \mathrm{mol}$ of reducing sugar as D-glucose per min. under the assay conditions. The results are presented as specific activity (U/mg extracellular protein). The results express the media $\pm \mathrm{SD}$ of three different experiments. $\mathrm{ND}=$ not determined.

The filtrates of starch and maltose cultures were dialyzed against water, the proteins concentrated by precipitation with acetone, and then loaded on to a DEAE-cellulose column at $\mathrm{pH}$ 6.8. In each case, the amylase activity was eluted in two peaks, designated as amylase I and II (Fig. 2). Approximately $70 \%$ of the total amylase activity was due to amylase II, and $30 \%$ was due to amylase I. The fractions with activity were pooled and concentrated by lyophilization. The enzymes were incubated with starch as substrate and, samples withdrawn periodlically from the reaction mixture were analysed by descending paper chromatography (Fig. 3). A mixture of sugars, larger oligosaccharides, traces of glucose and mainly maltose, was obtained from starch when the hydrolysis was carried out using the amylase II,
Table 3. Effect of temperature on amylase production by A. tamarii

\begin{tabular}{cccc}
\hline $\begin{array}{c}\text { temperature } \\
\left({ }^{\circ} \mathrm{C}\right)\end{array}$ & $\begin{array}{c}\text { biomass } \\
(\mathrm{mg})\end{array}$ & $\begin{array}{c}\text { glucoamylase } \\
(\mathrm{U} / \mathrm{mg})\end{array}$ & $\begin{array}{c}\alpha \text {-amylase } \\
(\mathrm{U} / \mathrm{mg})\end{array}$ \\
\hline 25 & $210 \pm 18$ & $129 \pm 15$ & $30 \pm 4$ \\
28 & $280 \pm 24$ & $128 \pm 11$ & $31 \pm 3$ \\
30 & $295 \pm 28$ & $136 \pm 12$ & $35 \pm 3$ \\
32 & $300 \pm 31$ & $130 \pm 16$ & $32 \pm 5$ \\
35 & $292 \pm 30$ & $129 \pm 10$ & $32 \pm 4$ \\
37 & $289 \pm 31$ & $120 \pm 15$ & $30 \pm 3$ \\
39 & $276 \pm 30$ & $125 \pm 15$ & $28 \pm 2$ \\
40 & $280 \pm 25$ & $122 \pm 12$ & $25 \pm 4$ \\
42 & $230 \pm 21$ & $119 \pm 10$ & $20 \pm 3$ \\
45 & $\mathrm{ND}$ & $\mathrm{ND}$ & $\mathrm{ND}$ \\
\hline
\end{tabular}

The cultures were grown in $250 \mathrm{ml}$ Erlenmeyer flasks containing $50 \mathrm{ml}$ minimal medium supplemented with $1 \%(\mathrm{w} / \mathrm{v})$ starch under static conditions for 6 days at different temperatures. The mycelia (biomass) were separated by filtration and dried to constant weigh at $60^{\circ} \mathrm{C}$. One unit of amylase (glucoamylase plus $\alpha$-amylase) was defined as the amount of enzymes that releases $1 \mu \mathrm{mol}$ of reducing sugar as D-glucose per min. under the assay conditions. The results are presented as specific activity (U/mg extracellular protein). The results express the media $\pm \mathrm{SD}$ of three different experiments. $\mathrm{ND}=$ not determined

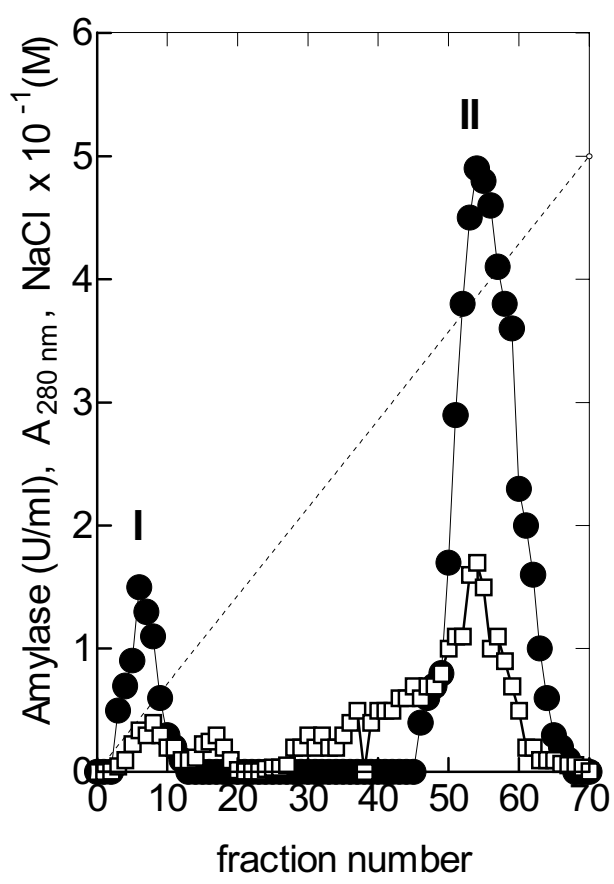

Figure 2. Distribution of protein and total amylase activities after DEAE-cellulose chromatography. (O) amylase activity; ( $\square$ ) absorbance at $280 \mathrm{~nm}$; (---) $\mathrm{NaCl}$ concentration. 


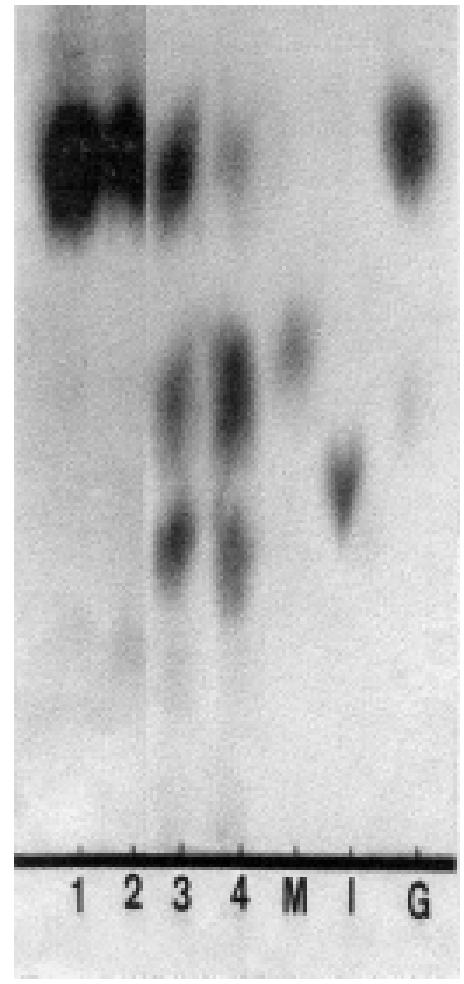

Figure 3. Paper chromatography of hydrolysis products from starch by amylase I and II. 1 and 2: starch plus amylase I (glucoamylase) after 30 and $60 \mathrm{~min}$. of incubation, respectively as described in MATERIALS AND METHODS; 3 and 4: starch plus amyalse II ( $\alpha$-amylase) after 30 and $60 \mathrm{~min}$. of incubation, respectively. M, I, and $\mathrm{G}$ are maltose, isomaltose and glucose standards, respectively. suggesting that this fraction contained an $\alpha$-amylase. Amylase I released only glucose from starch, indicating that this fraction contained a glucoamylase.

Some properties of amylases were studied. The effect of $\mathrm{pH}$ on the glucoamylase and $\alpha$-amylase was studied using starch as the substrate in McIlvaine buffers (Fig. 4). The initial rate of starch hydrolysis at $40^{\circ} \mathrm{C}$ was maximal at $\mathrm{pH} 4.5-5.0$, but substantial activities were detected at $\mathrm{pH}$ values ranging from 4.0 to 7.0 (Fig. $4 \mathrm{~A}$ ). At $40^{\circ} \mathrm{C}$ and $\mathrm{pH} 4.0$ to 7.2 , the enzymes were stable for 2 days (data not shown). These data are in agreement with the general behaviour reported for other fungal amylases $(5,11)$ The recommended $\mathrm{pH}$ range for hydrolysis of starch with commercially available fungal amylases is between 4.0 and 4.5 (3) and the higher $\mathrm{pH}$ range observed may have the advantage of requering less adjustment of $\mathrm{pH}$ between sequential $\alpha$-amylase (liquefaction) and glucoamylase (saccharification) treatments. The enzymes were highly active over a broad temperature range of $40-70^{\circ} \mathrm{C}$. At $\mathrm{pH} 6.0$, the optimal activity was observed at a temperature of $50-55^{\circ} \mathrm{C}$ for both enzymes (Fig. 4B) Thermal inactivation of the partialy purified amylases was investigated by incubating the enzymes at $55^{\circ} \mathrm{C}$ and $65^{\circ} \mathrm{C}$ in $0.05 \mathrm{M}$ sodium phosphate buffer, pH 6.0, without substrate (Fig. 4C). The enzymes were stable at $55^{\circ} \mathrm{C}$ for more than 10 hours, and at $65^{\circ} \mathrm{C}$ exhibited an half-life of $30 \mathrm{~min}$. (amylase I) and 45 min. (amylase II).

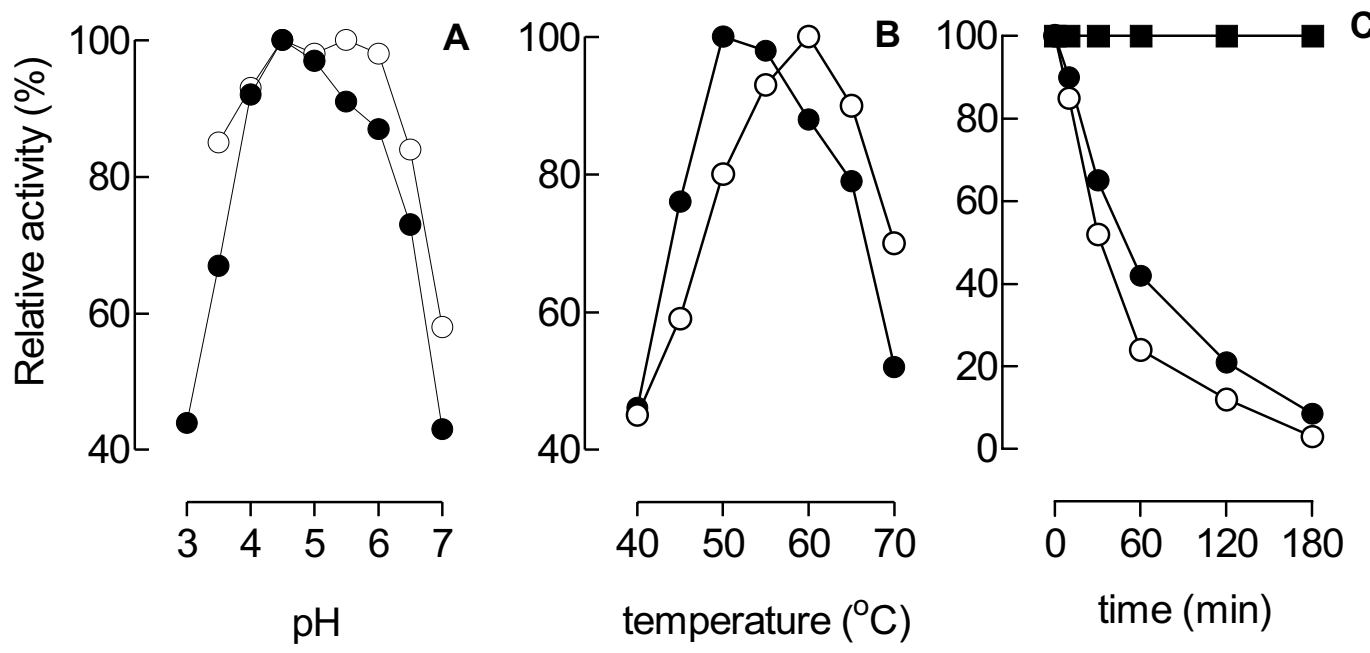

Figure 4. Effect of $\mathrm{pH}(\mathrm{A})$ and temperature (B) on the activity and effect of temperature on the stability (C) of amylases from Aspergillus tamarii. A and B: $\left(-\right.$ glucoamylase activity; $(\bigcirc) \alpha$-amylase activity; C: $(\square)$ residual glucoamylase and $\alpha$-amylase activities at $55^{\circ} \mathrm{C}$; (O) residual $\alpha$-amylase activitiy at $65^{\circ} \mathrm{C}$; (O) residual glucoamylase activity at $65^{\circ} \mathrm{C}$. 
Some characteristics of $A$. tamarii described in this paper, such as easy cultivation, production of two types of amylases (glucoamylase and $\alpha$-amylase) on cultures at different $\mathrm{pH}$ and temperature conditions, and stability of the enzymes at an acidic range of $\mathrm{pH}$, make this fungus a potential source of amylase for future biotechnological applications. Purification of these amylases is in progress in our laboratory.

\section{ACKNOWLEDGEMENTS}

This work was supported by the Conselho Nacional de Desenvolvimento Científico e Tecnológico (CNPq) and Universidade Estadual de Maringá. The authors are grateful to M.A.F.Costa for her technical assistance.

\section{RESUMO}

\section{Produção de amilases por Aspergillus tamarii}

Uma cepa de Aspergillus tamarii, um fungo filamentoso isolado do solo, foi hábil em produzir $\alpha$-amilase e glucoamilase em meio mineral suplementado com amido ou maltose a $1 \%(\mathrm{p} / \mathrm{v})$ como fonte de carbono. A produção de amilases em culturas estacionárias foi significativamente maior do que em culturas sob agitação. Uma ampla faixa de $\mathrm{pH}$ inicial (de 4 a 10$)$ e temperatura $\left(\operatorname{de~} 25 \mathrm{a} 42^{\circ} \mathrm{C}\right)$ pode ser utilizada nos cultivos para a produção das amilases. Duas amilases, uma $\alpha$-amilase e uma glucoamilase foram separadas por cromatografia de troca iônica. As enzimas parcialmente purificadas exibiram máxima atividade na faixa de $\mathrm{pH}$ entre 4,56,0 apresentando grande estabilidade sob condições ácidas (pH 4 a 7). Máxima atividade foi obtida nas temperaturas entre 50 e $60^{\circ} \mathrm{C}$, e as enzimas foram estáveis por mais de dez horas à $55^{\circ} \mathrm{C}$.

Palavras-chave: $\alpha$-amilase, Aspergillus tamarii, glucoamilase.

\section{REFERENCES}

1. Bergmeyer, H.U.; Bernt, E. D-glucose determination with glucose oxidase and isomerase. In: Bergmeyer, H.U., (ed). Methods of enzymatic analysis. Verlag/Chimie/Academic Press, New York, 1974, p. 1205-1212.

2. Bowles, L.L. Amylolytic enzymes. Food Sci. Technol., 75,105-129, 1996.

3. Boyce, C.O L. Novo's Handbook of practical biotechnology. Novo Industry A/S, Bagsvaerd, Denmark, 1986.

4. Bradford, M. A rapid and sensitive method for the quantification of microgram quantities of protein utilizing the principle of dye-binding. Anal. Biochem., 72, 248-254, 1976.

5. Ghosh, A.; Chatergee, B.; Das, A. Purification and characterization of glucoamylase from Aspergillus terreus NA-170 mutant. J. Appl. Bacteriol., 71, 162-169, 1991.

6. Herbert, D.; Phipps, P.J.; Strange, R.E. Chemical analysis of microbial cells. In: Norris, J.R. and Ribbons, D.W (eds). Methods in Microbiology. Academic Press, New York, 1971, p. 210-344.

7. Kadowaki, M.K.; Souza, C.G.M.; Simão, R.C.G. and Peralta, R.M. Xylanase production by Aspergillus tamarii. Appl. Biochem. Biotechnol. 66,97-106, 1997.

8. MacGregor, E. A. Structure and activity of some starchmetabolizing enzymes. Prog. Biotechnol., 12, 109-124, 1996.

9. Miller, G.L. Use of dinitrosalicylic acid reagent for determination of reducing sugar. Anal. Chem., 31, 426-428, 1959.

10. Montenecourt, B.S.; Eveileigh, D.E. Preparation of mutants of Trichoderma reesei with enhanced cellulase production. Appl. Environ. Microbiol., 34, 777-784, 1977.

11. Pazur, P.J.; Liu, B.; Miskiel, F.J. Comparison of properties of glucoamylases from Rhizopus niveus and Aspergillus niger. Biotechnol. Appl. Biochem., 12, 63-78, 1990.

12. Ray, R.R.; Jana, S.C.; Nanda, G. Induction and catabolite repression in the biosynthesis of $\beta$-amylase by Bacillus megaterium B6. Biochem. Mol. Biol. Int., 38, 223-230, 1996.

13. Ray, R.R.; Nanda, G. Microbial $\beta$-amylases: biosynthesis, characteristics, and industrial applications. Crit. Rev. Microbiol., 22, 181-199, 1996.

14. Sadhukhan, R.K.; Roy, S.K.; Raha, S.K.; Manna, S.; Chakrabarty, S.L. Induction and regulation of $\alpha$-amylase synthesis in a cellulolytic thermophilic fungus Myceliophthora thermophila D14(ATCC 48104). Ind. J. Exp. Biol., 30, 482-486, 1992.

15. Saha, B.C.; Zeikus, J.G. Microbial glucoamylases: biochemical and biotechnological features. Starch Staerke, 41, 57-64, 1989.

16. Sinkar, V.P.; Lewis, N.F. Glucoamylase production by a newly isolate strain of Aspergillus niger. J. Food Protect., 45, 586589,1982

17. Trevelyàn, W.E.; Procter, D.P.; Harrison, J.G. Detection of sugars on paper chromatograms. Nature, 166, 444-445, 1950.

18. Vihinen, M.; Mäntsälä, P. Microbial amylolytic enzymes. Crit. Rev. Biochem. Mol. Biol., 24, 329-418, 1989. 